\title{
FLORA MALESIANA PRECURSOR FOR THE TREATMENT OF MORACEAE
}

\author{
C.C. BERG \\ The Norwegian Arboretum/Botanical Institute, University of Bergen, \\ N-5259 Hjellestad, Norway; Nationaal Herbarium Nederland, Universiteit Leiden branch, \\ P.O. Box 9514, 2300 RA Leiden, The Netherlands
}

\section{ERRATA}

The following errors in precursor 3. subgen. Ficus, Blumea 48 (2003) 529-550, have to be corrected:

1) p. 529, 539, 540, 548: Ficus kofmanae into Ficus kofmaniae.

2) p. 537: subgen. roxburghii (Miq.) C.C. Berg into subgen. Roxburghii (King) C.C. Berg. See Mabberley (1980) 90.

\section{REFERENCE}

Mabberley, D.J. 1980. A re-examination of the 'Indian catalogies' with particular reference to Hortus Malabaricus. In: K.S. Maninal (ed.), Botany and history of Hortus Malabaricus: 80-110. Rotterdam. 